\title{
Synthesis, Spectral Study and Theoretical Treatment of Some Transition Metal Complexes of 5-(4-Nitro Phenyl)-4-Amino-3-Mercapto Propenyl-1,2,4-Triazole Ligand
}

\author{
Mahasin Alias*, Ameena N. Seewan*, Sura Khalil* and Carolin Shakir** \\ "Department of Chemistry, College of Science for Women, University of Baghdad, Baghdad-Iraq. \\ ${ }^{* *}$ Central Organization for Standardization and Quality Control, Ministry of Planning, \\ Baghdad-Iraq.
}

\section{Abstract}

In the present work, we synthesized a series of metal complexes of $\mathrm{Co}(\mathrm{II}), \mathrm{Ni}(\mathrm{II}), \mathrm{Cu}(\mathrm{II}), \mathrm{Zn}(\mathrm{II})$ and $\mathrm{Au}(\mathrm{III})$ from newly synthesized ligand 5-(4-Nitro Phenyl)-4-Amino-3-Mercapto Propenyl1,2,4-Triazole (L) in alcoholic medium. These compounds were characterized by several techniques using FT-IR, UV-Visible spectrophotometer, thermal gravimetric TG analyses, magnetic susceptibility, Flame Atomic Absorption technique, elemental analysis and conductivity measurements. From the spectral studies, an octahedral monomer structure was proposed for all complexes except $\mathrm{Cu}(\mathrm{II})$ complex has dinuclear structure. The nature of the complexes formed in ethanolic solution has been studied following the molar ratio method and the result recorded 1:1 molar ratio for all complexes. Semi-empirical methods (ZINDO/1, ZINDO/S and PM3) were carried out to evaluate the heat of formation $\Delta \mathrm{H}^{\circ} \mathrm{f}$, binding energy $\Delta \mathrm{E}_{\mathrm{b}}$, and dipole moment for all complexes expect $\mathrm{Au}(\mathrm{III})$ complex that used AMBER method, also the vibration frequencies and electronic transitions were calculated for prepared ligand to make comparison with experimental results. Electrostatic potential, HOMO and LUMO energies for ligand were calculated to determine the reactive sites of new ligand.

Keywords: 5-(4- Nitro Phenyl)-4-Amino-3-Mercapto, Thermal gravimetric, Complexes, Semiempirical.

\section{Introduction}

In the last few decades, the chemistry of 1,2,4-traiazole compounds and their fused heterocyclic derivatives have received considerable attention owing of their synthetic and effective biological importance, for example, a large of 1,2,4-traiazole containing ring systems have been incorporated into a wide variety of therapeutically interesting drug candidates including anti-inflammatory, CNS stimulation sedatives, antianxiety and antimicrobial agents [1,2]. The mercapto and thione-substituted 1,2,4-traizole ring systems have been reported for a large number of their derivatives [1]. Bis(allyl) nickel $\left(\mathrm{C}_{3} \mathrm{H}_{5}\right) \mathrm{Ni}$, was the first homoleptic transition metal allayl complex to be isolated, and it is still the archetypal example of its class. A variety of both homoleptic and hetroleptic (allyl) nickel complexes have been prepared and studied in the ensuing 40 years, and many of them have found uses in homogenous catalysis and organic synthesis [3]. Many attempts have been made to synthesize a variety of complexes with paramagnetic centers by using such ligands, and their structures and magnetic properties have been characterized. However, the polynuclear $\mathrm{Ag}(\mathrm{I})$ complexes birding by 1,2,4-triazole have been poorly studies [4].

\section{Experimental}

\subsection{Instrumentation}

Elements like $\mathrm{C}, \mathrm{H}, \mathrm{N}$ and $\mathrm{S}$ were analyzed with EM-017.mth instrument, the FT-IR spectra in the range $(4000-200) \mathrm{cm}^{-1}$ were recorded on IR-Prestige-21, Single Beam Path Laser, Shimadzu Fourier Transform Infrared Spectrophotometer with samples prepared as CsI pellets and UV-Visible reflectance spectra were obtained using UV-1650PC Shimadzu spectrophotometer in range (200-1100) $\mathrm{nm}$. Thermal analysis TGA was performed with 4000 Perkin-Elmer thermal analyzer maintained at a $20.00{ }^{\circ} \mathrm{C} \mathrm{min}^{-1}$ heating rate. Magnetic susceptibilities were measured at room temperature on Magnetic Susceptibility Balance of Johnson mattey catalytic system division, England. Atomic Absorption measurements of the prepared complexes were obtained using Shimadzu Atomic Absorption 
680 Flame Spectrophotometer. The Conductivity values of the prepared complexes were measured using DMF as solvent, the concentration $10^{-3} \mathrm{M}$ using (WTW) Conductometer. Melting point apparatus of Gallen Kamp M.F.B-60 was used to measure melting points of all prepared compounds.

\subsection{Synthesis of compounds}

2.2.1. Preparation of ligand 5-(4-Nitro Phenyl)-4-Amino-3-Mercapto Propenyl1,2,4-Triazole $(L)$

A. Synthesis of methyl ester of 4nitrobenzoic acid (I) $[2,5]$

To 4-nitrobenzoic acid $(0.1 \mathrm{~mol})$ in $(100 \mathrm{ml})$ of methanol in a round bottomed flask conc. sulfuric acid $(5.7 \mathrm{ml})$ was added. The mixture was refluxed for $6 \mathrm{hrs}$, then cooled and neutralized with $5 \%$ sodium bicarbonate the product was recrystallized from absolute ethanol. Yiled $90 \%$, m.p. $97-99{ }^{\circ} \mathrm{C}$.

\section{B. Synthesis of acid hydrazide of 4-} nitrobenzoic acid methyl ester (II) [2,5]

To hydrazide hydrate $(80 \%)(5.7 \mathrm{ml}$, $0.15 \mathrm{~mol}$ ) in a flat bottomed flask a solution of compound (I) $(0.1 \mathrm{~mol})$ in $30 \mathrm{ml}$ of ethanol was added drop wise with gently stirring. After complete addition, the mixture was transferred into round bottomed flask and refluxed for 5 hrs. Ethanol was distilled off under dried reduce pressure. The precipitate of acid hydrazide was filtered and recrystallized from ethanol. Yiled $80 \%$, m.p. $218-220^{\circ} \mathrm{C}$.

\section{Synthesis of potassium 3-(4-nitrobenzoyl) dithiocarbazate (III)}

A mixture of potassium hydroxide $(0.15 \mathrm{~mol}), 100 \mathrm{ml}$ of absolute ethanol and (0.1 mol) of compound (II) was treated with $(0.15 \mathrm{~mol})$ of carbon disulfide. This mixture was diluted with $75 \mathrm{ml}$ of absolute ethanol and stirred for $16 \mathrm{hrs}$. The solvent was evaporated under reduce pressure; the salt was employed without further purification.

\section{Synthesis of 5-(4-nitrophenyl) 4-amino-3- mercapto-1,2,4-triazole (IV)}

A suspension of $(0.1 \mathrm{~mol})$ of compound (III) in absolute alcohol, $(0.2 \mathrm{~mol})$ of hydrazide hydrate and $6 \mathrm{ml}$ of water were refluxed for $3 \mathrm{hrs}$. The colour of the reaction mixture changed to green with the evolution of hydrogen sulfide gas and a homogenous solution resulted. Cold distilled water $(100 \mathrm{ml})$ was added and the solution was acidified with conc. $\mathrm{HCl}$. The solid precipitate was filtered, washed with $2 \times 30 \mathrm{ml}$ portions of cold water, and recrystallized. Yiled $66 \%$, m.p. $180-182^{\circ} \mathrm{C}$.

\section{E. Synthesis of 5-(4-nitrophenyl) 4-amino-3- mercapto propenyl-1,2,4-triazole (L)}

To a stirred solution of compound (IV) $(0.003 \mathrm{~mol})$ in $15 \mathrm{ml}$ absolute ethanol, $\mathrm{KOH}$ $(0.003 \mathrm{~mol})$ was added slowly. To the stirred reaction mixture, appropriate allyl bromide $(0.003 \mathrm{~mol})$ was added drop wise and the mixture was refluxed for $1 \mathrm{hr}$, after cooling, filtered and the filtrate were poured into icecold water $(500 \mathrm{ml})$ the crude product was recrystallized from ethanol Scheme (1). Shows the interaction of the prepared compounds and Table (1) illustrated the physical data of $\mathrm{L}$ and its complexes. 


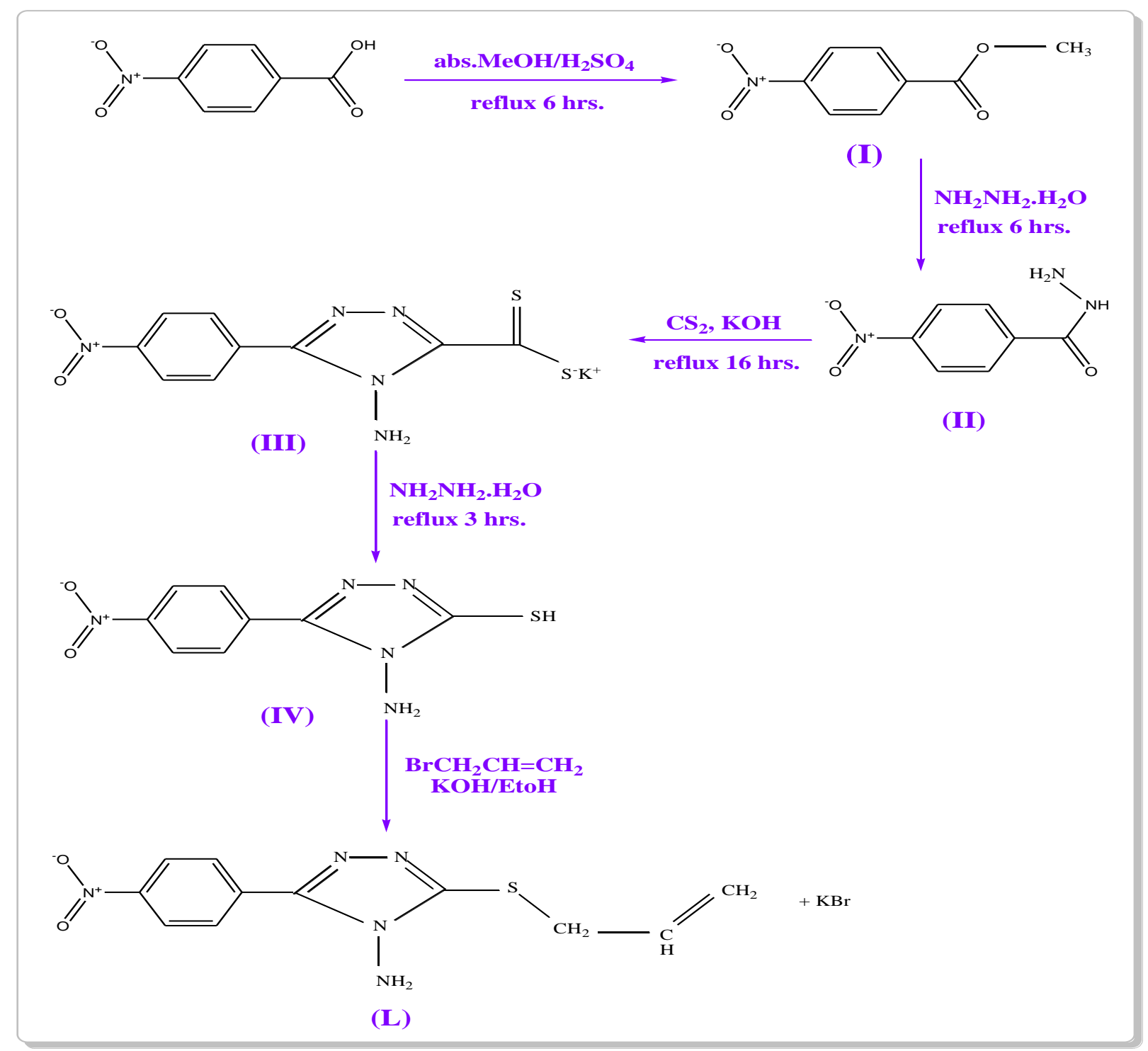

Scheme (1) General steps of synthesis 5-(4-nitrophenyl) 4-amino-3-mercapto propenyl-1,2,4triazole $(L)$.

\subsubsection{Synthesis of metal complexes}

A solution of $(1$ mmole $)$ of $\left(\mathrm{Co}\left(\mathrm{NO}_{3}\right)_{2} \cdot 6 \mathrm{H}_{2} \mathrm{O}, \mathrm{Ni}\left(\mathrm{NO}_{3}\right)_{2} \cdot 6 \mathrm{H}_{2} \mathrm{O}, \mathrm{Cu}\left(\mathrm{NO}_{3}\right)_{2} \cdot 3 \mathrm{H}_{2} \mathrm{O}\right.$ or $\mathrm{Zn}\left(\mathrm{CH}_{3} \mathrm{COO}\right)_{2} \cdot 2 \mathrm{H}_{2} \mathrm{O}$ or $\left.\mathrm{HAuCl}_{4} \cdot \mathrm{H}_{2} \mathrm{O}\right)$ dissolved in $2 \mathrm{ml}$ of absolute ethanol was added drop by drop to ( 1 mmole) of ligand dissolved in $10 \mathrm{ml}$ of absolute ethanol. The mixture was heated with stirring for $15 \mathrm{~min}$; the resulting precipitate was filtered off, washed with distilled water then dried under vacuum, the physical properties of the prepared complexes listed in Table (1). 
Table (1)

Physical data of new ligand and its metal complexes.

\begin{tabular}{|c|c|c|c|c|c|c|c|c|c|}
\hline \multirow{2}{*}{ Comp. } & \multirow{2}{*}{ Colour } & \multirow{2}{*}{$m . p .{ }^{\circ} \mathrm{C}$} & \multirow{2}{*}{ Yield\% } & \multirow{2}{*}{$\begin{array}{l}\text { M.Wt } \\
\text { g.mol }\end{array}$} & \multicolumn{5}{|c|}{ Found (calc.)\% } \\
\hline & & & & & $C$ & $\mathrm{H}$ & $N$ & $S$ & $M$ \\
\hline $\mathbf{L}$ & Yellow & $\begin{array}{l}176- \\
178\end{array}$ & 63.00 & 277.00 & $\begin{array}{c}46.71 \\
(47.65)\end{array}$ & $\begin{array}{c}3.55 \\
(3.97)\end{array}$ & $\begin{array}{c}25.01 \\
(25.27)\end{array}$ & $\begin{array}{c}10.11 \\
(11.02)\end{array}$ & ---- \\
\hline $\begin{array}{c}\left.\mathrm{CoL}\left(\mathrm{H}_{2} \mathrm{O}\right)_{3}\right] \\
\left(\mathrm{NO}_{3}\right)_{2} .3 \mathrm{EtOH} \\
\end{array}$ & Brown & $78 \mathrm{~d}$ & 76.19 & 651.93 & $\begin{array}{c}\text { 30.51 } \\
(31.29) \\
\end{array}$ & $\begin{array}{c}4.55 \\
(5.36) \\
\end{array}$ & $\begin{array}{c}14.63 \\
(15.03)\end{array}$ & $\begin{array}{c}4.08 \\
(4.90)\end{array}$ & $\begin{array}{c}8.10 \\
(9.00)\end{array}$ \\
\hline $\begin{array}{c}{\left[\mathrm{NiL}\left(\mathrm{H}_{2} \mathrm{O}\right)_{3}\right]} \\
\left(\mathrm{NO}_{3}\right)_{2} .3 \mathrm{EtOH} \\
\end{array}$ & $\begin{array}{c}\text { Orang } \\
\text { e }\end{array}$ & $101 \mathrm{~d}$ & 78.94 & 651.69 & $\begin{array}{l}\text { 30.16 } \\
(31.30)\end{array}$ & $\begin{array}{c}4.30 \\
(5.06)\end{array}$ & $\begin{array}{c}14.51 \\
(15.03)\end{array}$ & $\begin{array}{c}4.14 \\
(4.91)\end{array}$ & $\begin{array}{c}9.12 \\
(9.00)\end{array}$ \\
\hline $\begin{array}{c}{\left[\mathrm{Cu}_{2}(\mathrm{~L})_{2}\left(\mathrm{NO}_{3}\right)_{4}\right] .} \\
\text { EtOH }\end{array}$ & $\begin{array}{c}\text { Dark } \\
\text { brown }\end{array}$ & $80 \mathrm{~d}$ & 60.00 & 975.00 & $\begin{array}{l}28.42 \\
(29.53)\end{array}$ & $\begin{array}{c}2.56 \\
(2.46)\end{array}$ & $\begin{array}{l}19.10 \\
(20.10)\end{array}$ & $\begin{array}{c}5.51 \\
(6.56)\end{array}$ & $\begin{array}{l}13.58 \\
(13.02)\end{array}$ \\
\hline$\left[\mathrm{ZnL}(\mathrm{OAC})_{2} \mathrm{H}_{2} \mathrm{O}\right]$ & $\begin{array}{l}\text { Dark } \\
\text { yellow }\end{array}$ & $\begin{array}{l}188- \\
190\end{array}$ & 60.44 & 478.00 & $\begin{array}{l}38.23 \\
(37.65)\end{array}$ & $\begin{array}{c}2.98 \\
(3.97)\end{array}$ & $\begin{array}{l}15.60 \\
(14.64)\end{array}$ & $\begin{array}{c}6.12 \\
(6.68)\end{array}$ & $\begin{array}{c}14.20 \\
(13.66)\end{array}$ \\
\hline $\begin{array}{c}\text { [AuLCl]Cl } \\
\text { EtOH }\end{array}$ & Brown & $89 \mathrm{~d}$ & 63.75 & 810.46 & $\begin{array}{c}29.54 \\
(29.61) \\
\end{array}$ & $\begin{array}{c}4.21 \\
(4.80) \\
\end{array}$ & $\begin{array}{c}7.59 \\
(8.63) \\
\end{array}$ & $\begin{array}{c}3.53 \\
(3.94) \\
\end{array}$ & $\begin{array}{c}23.90 \\
(24.30) \\
\end{array}$ \\
\hline
\end{tabular}

$d=$ decomposition degree .

\subsection{Study of complexes formation in solution state}

Complexes of new ligand with metal ions have been studied in solution state using ethanol as a solvent, in order to determine [M/L] ratio in the complexes follow molar ratio method [6]. A series of solutions have been prepared having a constant concentration $10^{-3} \mathrm{M}$ for each metal ion and ligand. The ratio have been determined from the relationship between the absorption of the absorbed light and molar ratio of (M:L) at $\lambda_{\max }$ of maximum absorption. The results of complexes in ethanol suggest that the metal to ligand ratio was [1:1] for all prepared complexes which were similar to that obtained from solid state study.

\section{Results and Discussion}

The elemental analysis shows 1:1 (metal:ligand) stoichiometry for the prepared complexes. The analytical data together with some physical properties of the complexes are summarized in Table (1). The isolated solid complexes are stable at room temperature and insoluble in common organic solvents except in DMF and DMSO. The molar conductance values of the complexes indicating that the all complexes are ionic expect $\mathrm{Cu}(\mathrm{II})$ and $\mathrm{Zn}(\mathrm{II})$ complexes which are non ionic. The formation and this geometry were further confirmed by FTIR, UV-Vis, TG, molar ratio and magnetic susceptibility studies.

\subsection{Infrared Spectra}

The FT-IR spectra analyses gave good information about the mode of coordination of the new ligand to the metallic ions; the characteristic bands are presented in Table (2). The spectrum of this ligand showed essential bands which belong to olefin group at $1558 \mathrm{~cm}^{-1}$ another bands at $864 \mathrm{~cm}^{-1}$ which originated from the out of plan bending vibration of the vinylic group [7]. These bands undergoes shifting to higher frequencies in all complexes about $\left(\sim 12-31 \mathrm{~cm}^{-1}\right)$ in olefin group $\mathrm{C}=\mathrm{C}$, also the stretching frequency related to $v(\mathrm{CH})$ olefin was shifted to higher frequencies by $\left(\sim 23-31 \mathrm{~cm}^{-1}\right)$ expect in $\mathrm{Zn}$ (II) complex undergoes shift to lower frequency, while the bending band of $\delta=\mathrm{CH}_{2}$ group shifted to lower frequencies $\left(227-62 \mathrm{~cm}^{-1}\right)$ in all complexes this indicated that the ligand is coordinated with metals by Pi bond, this coordination was supported by appearance of $v(\mathrm{M}-\mathrm{C})$ band in the range $\left(420-435 \mathrm{~cm}^{-1}\right)$ in all complexes[8,9]. The bands appeared at 3441 and $3360 \mathrm{~cm}^{-1}$ region due to the stretching frequency of asymmetric and symmetric $\mathrm{NH}_{2}$ group, the results recorded disappearance of these bands in all complexes, while band of stretching mode of $\mathrm{N}-\mathrm{N}$ band is remained without change in all complexes at $1014 \mathrm{~cm}^{-1}$, another band appeared at $752 \mathrm{~cm}^{-1}$ which attributed to $v(\mathrm{C}-\mathrm{S})$ band which undergoes a shifting to lower frequencies in all complexes expect $\mathrm{Au}(\mathrm{III})$ which show a slight shift to higher 
frequency, which support coordination of ligand with metal ions by these group i.e. $\mathrm{NH}_{2}$ and $\mathrm{C}-\mathrm{S}$ in addition to pi bond, the result reflect the tridentate behavior of this new ligand with all metal complexes, more evidence new bands appeared in the range (450-468 $\left.\mathrm{cm}^{-1}\right)$ and $\left(455-495 \mathrm{~cm}^{-1}\right)$ due to the stretching frequency of (M-S) and (M-N) bond $[8,9]$.

Table (2)

Most diagnosis FTIR bands of the ligand and its metal complexes in $\left(\mathrm{cm}^{-1}\right)$.

\begin{tabular}{|c|c|c|c|c|c|c|c|c|c|c|}
\hline Comp. & $v \mathrm{NH}_{2}$ & $v(C=C)$ & $\begin{array}{l}v(\mathrm{CH}) \\
\text { olefin } \\
\end{array}$ & $\delta=C H_{2}$ & $v(C-S)$ & $v N-N$ & $v(M-C)$ & $\begin{array}{c}v(M- \\
N) \\
\end{array}$ & $v(M-S)$ & Other \\
\hline $\mathbf{L}$ & $\begin{array}{l}3441 \mathrm{~m} \\
3360 \mathrm{w}\end{array}$ & $1558 \mathrm{sh}$ & $3035 \mathrm{~m}$ & $864 \mathrm{w}$ & $752 \mathrm{~m}$ & $1014 \mathrm{w}$ & --- & --- & --- & --- \\
\hline $\begin{array}{c}{\left[\mathrm{CoL}\left(\mathrm{H}_{2} \mathrm{O}\right)_{3}\right]} \\
\left(\mathrm{NO}_{3}\right)_{2} .3 \mathrm{EtO} \\
\mathbf{H}\end{array}$ & --- & $1570 \mathrm{w}$ & $3062 \mathrm{w}$ & $829 \mathrm{w}$ & $694 \mathrm{w}$ & $1014 \mathrm{w}$ & $428 \mathrm{~m}$ & $489 \mathrm{~s}$ & $462 w$ & $\begin{array}{c}\mathrm{vNO}_{3} 1365, \\
1234,1200 \\
\text { v EtOH } 3550 \\
\delta \mathrm{H}_{2} \mathrm{O} 829 \mathrm{w}\end{array}$ \\
\hline $\begin{array}{c}{\left[\mathrm{NiL}\left(\mathrm{H}_{2} \mathrm{O}\right)_{3}\right]} \\
\left(\mathrm{NO}_{3}\right)_{2} .3 \mathrm{EtO} \\
\mathbf{H}\end{array}$ & --- & $1581 \mathrm{w}$ & $3062 \mathrm{w}$ & $802 \mathrm{w}$ & $694 \mathrm{w}$ & $1014 \mathrm{w}$ & $420 \mathrm{~m}$ & $486 w$ & $468 w$ & 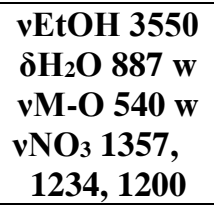 \\
\hline $\begin{array}{c}{\left[\mathrm{Cu}_{2}(\mathrm{~L})_{2}\left(\mathrm{NO}_{3}\right)\right.} \\
4] . \mathrm{EtOH}\end{array}$ & --- & 1573 w & $3062 \mathrm{w}$ & $810 \mathrm{w}$ & $694 \mathrm{w}$ & $1014 \mathrm{w}$ & $424 \mathrm{sh}$ & $487 \mathrm{sh}$ & $451 w$ & $\begin{array}{c}\mathrm{vONO}_{2} 1342, \\
1288,1180 \\
\text { vEtOH } 3350 \\
\text { vM-O } 516 \text { w } \\
\text { vNO } 1354, \\
1234,1200\end{array}$ \\
\hline $\begin{array}{c}\mathrm{ZnL}(\mathrm{OAC})_{2} \\
\left.\mathrm{H}_{2} \mathrm{O}\right]\end{array}$ & --- & $1581 \mathrm{~s}$ & $3012 \mathrm{w}$ & $833 w$ & $729 w$ & $1014 \mathrm{w}$ & $435 \mathrm{sh}$ & $455 w$ & $425 w$ & $\begin{array}{l}v \text { OAC } 1581 \\
\delta H_{2} O 833 \text { w }\end{array}$ \\
\hline $\begin{array}{c}{[\mathrm{AuLCl}] \mathrm{Cl}_{2}} \\
\text { EtOH }\end{array}$ & --- & $1589 \mathrm{~s}$ & $3066 \mathrm{w}$ & 837 w & $760 \mathrm{~m}$ & $1014 \mathrm{w}$ & $420 \mathrm{sh}$ & $495 \mathrm{sh}$ & $450 \mathrm{w}$ & $\begin{array}{c}v(\mathrm{AuCl}) 320 \\
\text { sh } \\
v \mathrm{EtOH} 3625 \\
\mathrm{v} \text { M-O } 497 \mathrm{w}\end{array}$ \\
\hline
\end{tabular}

Where: $w=w e a k, s=$ strong, $m=$ medium, sh=sharp.

\subsection{Electronic spectra and magnetic moment study}

\subsubsection{Ligand}

The spectrum of new ligand exhibited three main bands which can be assigned to the alkene and imine group. The first absorption band appeared at $260 \mathrm{~nm}\left(38461 \mathrm{~cm}^{-1}\right)$ due to intra ligand $\left(\pi \rightarrow \pi^{*}\right)$ transition located on the $-\mathrm{C}=\mathrm{C}-$ group. The second absorption band appeared at $271 \mathrm{~nm}\left(36900 \mathrm{~cm}^{-1}\right)$ arise from $\left(\mathrm{n} \rightarrow \pi^{*}\right)$ transition within the $-\mathrm{C}=\mathrm{N}-$ group. The third band appeared at $355 \mathrm{~nm}\left(28169 \mathrm{~cm}^{-1}\right)$ also attributed to $\left(\mathrm{n} \rightarrow \pi^{*}\right)$ transition located on the nitrogen atom of the imine group [8].

\subsubsection{Co(II) complex}

The value of the magnatic measurment (4.52) B.M indicates that the brown $\mathrm{Co}(\mathrm{II})$ complex to be paramagnatic and is characteristic of high spin cobalt ion in octahedral geometry species. The spectrum of this complex showd two bands at 19230 and $25062 \mathrm{~cm}^{-1}$ which attrbiuted to $v_{2}$ and $v_{3}$ respectivly[10], the value of first transtion was calculated therotically and found to be $10864 \mathrm{~cm}^{-1}$. The difrrent ligand filed parameters have been calculated using Tanaba-Sugano di 
agram for $\mathrm{d}^{7}$ system, the results are found in Table (3). Condictavity mesurments refers to ionic behaviour of this complex.

\subsection{3. $\mathrm{Ni}(\mathrm{II})$ complex}

The possible spin-allowed transition can be assigned as mentioned in Table (3) with their respective values. The value of the first transition $\boldsymbol{v}_{\boldsymbol{1}}$ which is equal to $10 \mathrm{Dq}$. The racah interelectronic repulsion parameters $B^{\prime}$ and the nephelauxetic factor $\beta$ were calculated by fitting the ratio $v_{3} / v_{2}$ to the Tanaba-Sugano diagram for octahedral $\mathrm{d}^{8}$ system. The transition observed at $14814.10 \mathrm{~cm}^{-1}$ is assigned to the spin-forbidden transition ${ }^{3} \mathrm{~A}_{2} \mathrm{~g} \rightarrow{ }^{1} \mathrm{Eg}[11,12]$. The conductivity measurements show that the complex is to be ionic.

\subsection{4. $\mathrm{Cu}(\mathrm{II})$ complex}

The spectrum of $\mathrm{CuL}$ complex showed only one broad band's at $12987 \mathrm{~cm}^{-1}$ which assigned to ${ }^{2} \mathrm{Eg} \rightarrow{ }^{2} \mathrm{~T}_{2} \mathrm{~g}$ transition. The spectrum also showed three bands at 26315, 27472 and $29850 \mathrm{~cm}^{-1}$ refers to charge transfer bands. The magnetic moment 0.65 B.M. of the dinuclear complex is in the range of octahedral geometry $[13,14]$. The conductivity measurements suggested that the complex to be non-ionic.

\subsubsection{Zn(II) complex}

The electronic spectrum of $\mathrm{ZnL}$ showed as expected shifting and change in shape of the bands compare with the ligand. The spectrum of prepared complex exhibited three bands at 27434, 29850 and $39215 \mathrm{~cm}^{-1}$ assigned to charge transfer bands [12]. The conductivity measurements indicate non-ionic behavior of this complex.

\subsection{6. $\mathrm{Au}(\mathrm{III})$ complex}

The spectrum of this complex showed two bands one at 27624 and $35824 \mathrm{~cm}^{-1}$ assigned to ${ }^{3} \mathrm{~A}_{2} \mathrm{~g} \rightarrow{ }^{3} \mathrm{~T}_{2} \mathrm{~g} \quad v_{1}$ and $\quad{ }^{3} \mathrm{~A}_{2} \mathrm{~g} \rightarrow{ }^{3} \mathrm{~T}_{1} \mathrm{~g}_{(\mathrm{F})} \quad v_{2}$ respectively in an octahedral geometry [15]. The spectrum also showed charge transfer band at $41322 \mathrm{~cm}^{-1}$. The conductivity measurements for this complex in DMF solvent at $25^{\circ} \mathrm{C}$ showed to be ionic Table (3).
Complexes of $\mathrm{Co}$ and $\mathrm{Ni}$ (II) are begin decomposition at $40{ }^{\circ} \mathrm{C}$, while $\mathrm{Zn}$ (II) at $55^{\circ} \mathrm{C}$ indicating the presence of water molecules inside the coordination sphere is confirmed by dynamic TG studies, in $\mathrm{Cu}$ (II) and $\mathrm{Au}(\mathrm{III})$ complexes exhibit the decomposition temperature at 75 and $90^{\circ} \mathrm{C}$ respectively, another peak appeared in all complexes except $\mathrm{Zn}$ (II) complex which assign to loss of ethanol group outside the coordination sphere. The decomposition of ligand exhibit in to two stage, another decomposition stages appeared at different temperature due to nitrate group in $\mathrm{Cu}(\mathrm{II}), \mathrm{Ni}(\mathrm{II})$, and $\mathrm{Co}(\mathrm{II})$ complexes, oxalate groups in $\mathrm{Zn}$ (II) complex as well as the decomposition of metal with sulphur atom of ligand. The stages of decompositions of the complexes can be summarized in Table (4).

\subsection{Thermal Gravimetric}


Table (3)

Electronic spectra, conductance in DMF solvent and magnetic moment (B.M.) for the prepared ligand and its metal complexes.

\begin{tabular}{|c|c|c|c|c|c|c|c|c|c|c|c|}
\hline Comp. & $\begin{array}{l}\text { Absorption } \\
\text { Bands }\left(\mathrm{cm}^{-1}\right) \\
\end{array}$ & Assignment & $\boldsymbol{B}^{\circ}$ & $B^{\prime}$ & $\boldsymbol{B}$ & $\begin{array}{c}D q / \\
B^{\prime} \\
\end{array}$ & $10 D q$ & $15 B^{\prime}$ & $\begin{array}{c}\mu_{e f f} \\
B . M .\end{array}$ & $\mu \mathrm{sm}^{-1}$ & $\begin{array}{c}\text { Suggested } \\
\text { geometry }\end{array}$ \\
\hline $\mathrm{L}$ & $\begin{array}{l}28164 \\
36900 \\
38461 \\
\end{array}$ & $\begin{array}{l}\mathrm{n} \rightarrow \pi^{*} \\
\pi \rightarrow \pi^{*} \\
\pi \rightarrow \pi^{*}\end{array}$ & --- & --- & --- & --- & --- & --- & --- & --- & --- \\
\hline $\begin{array}{c}{\left[\mathrm{CoL}\left(\mathrm{H}_{2} \mathrm{O}\right)_{3}\right]} \\
\left(\mathrm{NO}_{3}\right)_{2} .3 \mathrm{EtOH}\end{array}$ & $\begin{array}{c}10864 \text { (cal.) } \\
19230 \\
25062 \\
\end{array}$ & $\begin{array}{c}{ }^{4} \mathrm{~T}_{1} \mathrm{~g} \rightarrow{ }^{4} \mathrm{~T}_{2} \mathrm{~g} \\
{ }^{4} \mathrm{~T}_{1} \mathrm{~g} \rightarrow{ }^{4} \mathrm{~A}_{2} \mathrm{~g} \\
{ }^{4} \mathrm{~T}_{1} \mathrm{~g} \rightarrow{ }^{4} \mathrm{~T}_{1} \mathrm{~g}_{(\mathrm{F})} \\
\end{array}$ & 971 & 835.74 & 0.86 & 1.3 & 10864 & 11698.14 & 4.52 & 158 & O.h \\
\hline $\begin{array}{c}{\left[\mathrm{NiL}\left(\mathrm{H}_{2} \mathrm{O}\right)_{3}\right]} \\
\left(\mathrm{NO}_{3}\right)_{2} .3 \mathrm{EtOH}\end{array}$ & $\begin{array}{c}14814 \\
10177 \text { (cal.) } \\
17931 \\
26422 \\
29368 \\
\end{array}$ & $\begin{array}{c}{ }^{3} \mathrm{~A}_{2} \mathrm{~g} \rightarrow{ }^{1} \mathrm{Eg} \\
{ }^{3} \mathrm{~A}_{2} \mathrm{~g} \rightarrow{ }^{3} \mathrm{~T}_{2} \mathrm{~g} \\
{ }^{3} \mathrm{~A}_{2} \mathrm{~g} \rightarrow{ }^{3} \mathrm{~T}_{1} \mathrm{~g}_{(\mathrm{F})} \\
{ }^{3} \mathrm{~A}_{2} \mathrm{~g} \rightarrow{ }^{3} \mathrm{~T}_{1} \mathrm{~g}(\mathrm{P}) \\
\mathrm{L} \rightarrow \mathrm{NiCT}\end{array}$ & 1035 & 674.01 & 0.65 & 1.21 & 10177 & 19348 & 3.05 & 109.0 & O.h \\
\hline $\begin{array}{c}{\left[\mathrm{Cu}_{2}(\mathrm{~L})_{2}\left(\mathrm{NO}_{3}\right)_{4}\right]} \\
\mathrm{EtOH}\end{array}$ & $\begin{array}{l}12987 \\
26315 \\
27472 \\
29850 \\
\end{array}$ & $\begin{array}{c}{ }^{2} \mathrm{Eg} \rightarrow{ }^{2} \mathrm{~T}_{2} \mathrm{~g} \\
\mathrm{~L} \rightarrow \mathrm{CuCT} \\
\mathrm{L} \rightarrow \mathrm{CuCT} \\
\mathrm{L} \rightarrow \mathrm{CuCT} \\
\end{array}$ & --- & --- & --- & --- & --- & --- & 0.65 & 61.00 & O.h \\
\hline $\begin{array}{c}{\left[\mathrm{ZnL}(\mathrm{OAC})_{2}\right.} \\
\left.\mathrm{H}_{2} \mathrm{O}\right]\end{array}$ & $\begin{array}{l}27434 \\
29850 \\
39215 \\
\end{array}$ & $\begin{array}{l}\text { ILCT } \\
\text { ILCT } \\
\text { ILCT } \\
\end{array}$ & --- & --- & --- & --- & --- & --- & 0.00 & 7.20 & O.h \\
\hline$[\mathrm{AuLCl}] \mathrm{Cl}_{2} . \mathrm{EtOH}$ & $\begin{array}{l}27624 \\
35842 \\
41422 \\
\end{array}$ & $\begin{array}{l}{ }^{3} \mathrm{~A}_{2} \mathrm{~g} \rightarrow{ }^{3} \mathrm{~T}_{2} \mathrm{~g} \\
{ }^{3} \mathrm{~A}_{2} \mathrm{~g} \rightarrow{ }^{3} \mathrm{~T}_{1} \mathrm{~g} \\
\mathrm{~L} \rightarrow \mathrm{AuCT}\end{array}$ & --- & --- & --- & --- & --- & --- & 0.00 & 80.6 & O.h \\
\hline
\end{tabular}

ILCT: Internal ligand charge transfer.

Table (4)

Thermal analyses results for complexes.

\begin{tabular}{|c|c|c|c|c|}
\hline Comp. & $\begin{array}{c}\text { Dissociation } \\
\text { stages } \\
\end{array}$ & $\begin{array}{c}\text { Temp range in } T G \\
{ }^{\circ} \mathrm{C} \\
\end{array}$ & $\begin{array}{l}\text { Weight loss Found } \\
\text { (Calc.)\% }\end{array}$ & Decomposition assignment. \\
\hline $\begin{array}{c}{\left[\mathrm{CoL}\left(\mathrm{H}_{2} \mathrm{O}\right)_{3}\right]} \\
\left(\mathrm{NO}_{3}\right)_{2.3 E t O H}\end{array}$ & $\begin{array}{c}\text { Stage I } \\
\text { Stage II } \\
\text { Stage III } \\
\text { Stage IV } \\
\text { Stage V } \\
\text { Stage VI }\end{array}$ & $\begin{array}{c}40-110 \\
110-250 \\
250-310 \\
310-420 \\
420-800 \\
800-860 \\
\end{array}$ & $\begin{array}{c}8.36(8.28) \\
21.02(21.16) \\
19.30(19.02) \\
6.49(6.28) \\
31.61(31.29) \\
13.75(13.94)\end{array}$ & $\begin{array}{l}\text { Coordination water molecules. } \\
\text { Outer sphere EtOH. } \\
2 \mathrm{NO}_{3} \\
\text { Propenyl group } \mathrm{C}_{3} \mathrm{H}_{5} \text { of ligand. } \\
\mathrm{C}_{8} \mathrm{H}_{6} \mathrm{~N}_{5} \mathrm{O}_{2} \text { of ligand. } \\
\text { CoS }\end{array}$ \\
\hline $\begin{array}{c}{\left[\mathrm{NiL}\left(\mathrm{H}_{2} \mathrm{O}\right)_{3}\right]} \\
\left(\mathrm{NO}_{3}\right)_{2.3 E t O H}\end{array}$ & $\begin{array}{c}\text { Stage I } \\
\text { Stage II } \\
\text { Stage III } \\
\text { Stage IV } \\
\text { Stage V } \\
\text { Stage VI } \\
\end{array}$ & $\begin{array}{c}40-105 \\
105-250 \\
250-310 \\
310-420 \\
420-850 \\
850-900 \\
\end{array}$ & $\begin{array}{c}8.40(8.28) \\
21.00(21.17) \\
19.23(19.02) \\
6.43(6.29) \\
31.52(31.30) \\
13.66(13.91) \\
\end{array}$ & $\begin{array}{l}\text { Coordination water molecules. } \\
\text { Outer sphere EtOH. } \\
2 \mathrm{NO}_{3} \\
\text { Propenyl group } \mathrm{C}_{3} \mathrm{H}_{5} \text { of ligand. } \\
\mathrm{C}_{8} \mathrm{H}_{6} \mathrm{~N}_{5} \mathrm{O}_{2} \text { of ligand. } \\
\text { NiS } \\
\end{array}$ \\
\hline $\begin{array}{c}{\left[\mathrm{Cu}_{2}(\mathrm{~L})_{2}\left(\mathrm{NO}_{3}\right)_{4}\right]} \\
\text { EtOH }\end{array}$ & $\begin{array}{c}\text { Stage I } \\
\text { Stage II } \\
\text { Stage III } \\
\text { Stage IV } \\
\text { Stage V } \\
\end{array}$ & $\begin{array}{c}75-120 \\
120-180 \\
180-330 \\
330-840 \\
840-900 \\
\end{array}$ & $\begin{array}{c}4.97(4.71) \\
25.43(25.12) \\
8.09(8.41) \\
41.33(41.84) \\
19.13(19.59) \\
\end{array}$ & $\begin{array}{c}\text { Outer sphere EtOH. } \\
4 \mathrm{ONO}_{2} \\
\text { Propenyl group } 2 \mathrm{C}_{3} \mathrm{H}_{5} \text { of ligand. } \\
2 \mathrm{C}_{8} \mathrm{H}_{6} \mathrm{~N}_{5} \mathrm{O}_{2} \text { of ligand. } \\
2 \mathrm{CuS} \\
\end{array}$ \\
\hline $\begin{array}{c}{\left[\mathrm{ZnL}(\mathrm{OAC})_{2}\right.} \\
\left.\mathrm{H}_{2} \mathrm{O}\right]\end{array}$ & $\begin{array}{c}\text { Stage I } \\
\text { Stage II } \\
\text { Stage III } \\
\text { Stage IV } \\
\text { Stage V } \\
\end{array}$ & $\begin{array}{c}55-80 \\
80-220 \\
220-335 \\
335-740 \\
740-800 \\
\end{array}$ & $\begin{array}{c}3.41(3.76) \\
24.51(24.68) \\
8.29(8.57) \\
42.89(42.67) \\
20.12(20.37) \\
\end{array}$ & $\begin{array}{c}\text { Coordination water molecules } \\
\text { 2OAc } \\
\text { Propenyl group } \mathrm{C}_{3} \mathrm{H}_{5} \text { of ligand. } \\
\mathrm{C}_{8} \mathrm{H}_{6} \mathrm{~N}_{5} \mathrm{O}_{2} \text { of ligand. } \\
\mathrm{ZnS} \\
\end{array}$ \\
\hline $\begin{array}{l}{[\mathrm{AuLCl}] \mathrm{Cl}_{2} .} \\
\text { EtOH }\end{array}$ & $\begin{array}{c}\text { Stage I } \\
\text { Stage II }\end{array}$ & $\begin{array}{c}90-140 \\
140-250\end{array}$ & $\begin{array}{l}5.23(5.67) \\
4.98(5.05)\end{array}$ & $\begin{array}{c}\text { Outer sphere EtOH. } \\
\text { Propenyl group } \mathrm{C}_{3} \mathrm{H}_{5} \text { of ligand. }\end{array}$ \\
\hline
\end{tabular}




\begin{tabular}{|l||c||c||c||c|}
\hline & Stage III & $250-700$ & $38.76(38.31)$ & $\mathrm{C}_{8} \mathrm{H}_{6} \mathrm{~N}_{5} \mathrm{O}_{2}, \mathrm{Cl}_{3}$ of ligand. \\
& Stage IV & $700-750$ & $28.55(28.25)$ & $\mathrm{AuS}$ \\
\hline
\end{tabular}

\subsection{Solution study}

Molar ratio method suggested that the metal to ligand ratio was (1:1) for all complexes.

\subsection{Suggested structure of new complexes}
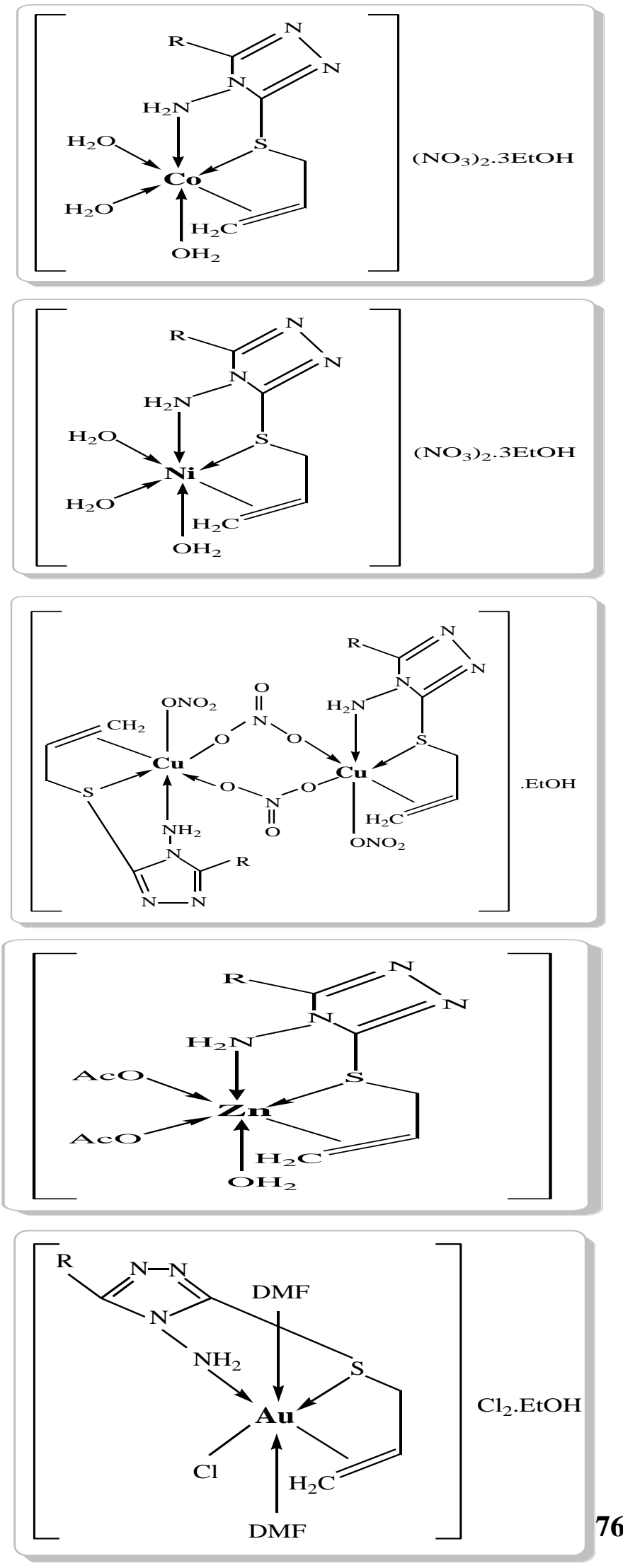

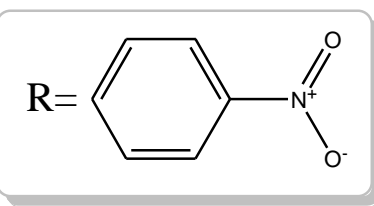

\section{Fig. (1) Suggested structure of the new prepared complexes.}

\subsection{Theoretical study}

The program Hyper Chem-8 was used for semi-empirical and molecular mechanical calculation at optimizing geometries, the results of calculations in gas phase i.e. heat of formation $\left(\Delta \mathrm{H}^{\circ} \mathrm{f}\right)$, binding energy $\left(\Delta \mathrm{E}_{\mathrm{b}}\right)$, and dipole moment $(\mu)$ for the free ligand and it metal complexes $\mathrm{Cu}(\mathrm{II}), \mathrm{Ni}(\mathrm{II}), \mathrm{Co}(\mathrm{II})$ and $\mathrm{Zn}$ (II) were calculated using ZINDO/1 method while AMBER method was using for $\mathrm{Au}$ (III) complex, Table (5). PM3 and ZINDO/S methods were used to evaluating the wave number and electronic transitions for the new ligand to compare with the experimental frequencies and transitions to support the results of experimental transitions. 
Table (5)

Conformation energetic (in K.J.mol ${ }^{-1}$ ) and dipole moment (in Debye) for ligand L and its metal complexes.

\begin{tabular}{|c|c|c|c|c|c|c|c|}
\hline \multirow{2}{*}{ Comp. } & \multicolumn{3}{|c|}{ PM3 } & \multicolumn{3}{|c|}{ ZINDO/1 } & \multirow{2}{*}{$\begin{array}{c}A M B E R \\
\Delta H_{f}^{\circ}=\Delta E_{b} \\
\end{array}$} \\
\hline & $\Delta H_{f}^{\circ}$ & $\Delta E_{b}$ & $\mu$ & $\Delta H_{f}^{\circ}$ & $\Delta E_{b}$ & $\mu$ & \\
\hline $\mathrm{L}$ & 496.13 & -12907.01 & 6.96 & -25686.94 & -39090.09 & 11.55 & --- \\
\hline $\begin{array}{c}\left.\mathrm{CoL}\left(\mathrm{H}_{2} \mathrm{O}\right)_{3}\right] \\
\left(\mathrm{NO}_{3}\right)_{2} .3 \mathrm{EtOH}\end{array}$ & ---- & ---- & ---- & -27363.90 & -42565.86 & 19.36 & ---- \\
\hline $\begin{array}{c}{\left[\mathrm{NiL}_{\left.\left(\mathrm{H}_{2} \mathrm{O}\right)_{3}\right]}\right.} \\
\left(\mathrm{NO}_{3}\right)_{2} .3 \mathrm{EtOH}\end{array}$ & ---- & ---- & ---- & -29738.35 & -46312.36 & 17.53 & ---- \\
\hline $\begin{array}{c}{\left[\mathrm{Cu}_{2}(\mathrm{~L})_{2}\left(\mathrm{NO}_{3}\right)_{4}\right]} \\
\mathrm{EtOH} \\
\end{array}$ & ---- & ---- & ---- & -56265.06 & -86187.42 & 13.63 & ---- \\
\hline $\begin{array}{c}\mathrm{ZnL}(\mathrm{OAC})_{2} \\
\left.\mathrm{H}_{2} \mathrm{O}\right]\end{array}$ & -1689.63 & -17008.69 & 15.96 & -36276.14 & -54974.46 & 25.21 & ---- \\
\hline$[\mathrm{AuLCl}] \mathrm{Cl}_{2} \mathrm{EtOH}$ & $\begin{array}{l}--- \\
\end{array}$ & $\begin{array}{l}--- \\
\end{array}$ & $\begin{array}{l}--- \\
\end{array}$ & $\begin{array}{l}--- \\
\end{array}$ & $\begin{array}{l}--- \\
\end{array}$ & ---- & 344.38 \\
\hline
\end{tabular}

The table above shown that the heat formation and binding energy of the new metal complexes is smaller than it for ligand. Thus, we expected that the complexes are to be thermodynamically more stable than the ligand itself.

Table (6)

Comparison of experimental and theoretical vibration frequencies for free ligands.

\begin{tabular}{|c|c|c|c|c|c|c|c|}
\hline Comp. & $v \mathrm{NH}_{2(1)}$ & $v \mathrm{NH}_{2(2)}$ & $v(C=C)$ & $\begin{array}{l}v(\mathrm{CH}) \\
\text { olefin }\end{array}$ & $\delta=C H_{2}$ & $v(C-S)$ & $v N-N$ \\
\hline $\mathrm{L}$ & $\begin{array}{c}3441.01 * \\
3514.53 * * \\
(2.9)^{* * *}\end{array}$ & $\begin{array}{r}3360.00^{*} \\
3394.74 * * \\
(1.0)^{* * *}\end{array}$ & $\begin{array}{c}1558.48 * \\
1792.71 * * \\
(15.0)^{* * *}\end{array}$ & $\begin{array}{c}3035.96 * \\
3144.54 * * \\
(3.5)^{* * *}\end{array}$ & $\begin{array}{c}864 * \\
926.62 * * \\
(7.2)^{* * *}\end{array}$ & $\begin{array}{c}752 * \\
795 * * \\
(-0.05)^{* * *}\end{array}$ & $\begin{array}{c}1014 * \\
1186.87^{* *} \\
(14.8)^{* * *}\end{array}$ \\
\hline
\end{tabular}

Where:*Experimental frequency, **Theoretical frequency, *** Error\% due to main different in the experimental measurements and theoretical treatment of vibration spectra.

The theoretical UV-spectra of ligand were calculated using ZINDO/S method and showed some deviations from the experimental values, these deviations are generally acceptable in theoretical calculations [16]. The serial number of atoms was plotted in the structure of ligand in can interpret the stereochemistry and rates of reactive sites of the molecule. Also, one many reactions involving soft order to determine the type of orbitals than type of transition Fig. (2). Theoretical spectrum of ligand exhibit three bands at 264.4, 322.9 and $388.3 \mathrm{~nm}$ assigned to $\pi \rightarrow \pi^{*}(\mathrm{C} 15 \rightarrow \mathrm{C} 14), \mathrm{n} \rightarrow \pi^{*}(\mathrm{~N} 8 \rightarrow \mathrm{C} 7)$ and $\mathrm{n} \rightarrow \pi^{*}(\mathrm{~N} 9 \rightarrow \mathrm{C} 10)$ respectively, which agree with experimental spectrum. The electrostatic potential (E.P.) describes the interaction of energy of the molecular system with a positive point charge.(E.P) of the ligand were plotted as two and three dimensions contours to investigate the electrophiles and nuclephiles in terms of the properties of frontier orbital's (HOMO \& LUMO). Overlap between the HOMO and LUMO is a governing factor in many reactions. The HOMO and LUMO value were plotted in two and three dimensions 
counter to get more information about these molecules (Fig. (3)). The results shows that the LUMO of transition metal ion prefers to react with HOMO of donor atoms of ligand.
Fig.(2) Serial number of atoms views of ligand.
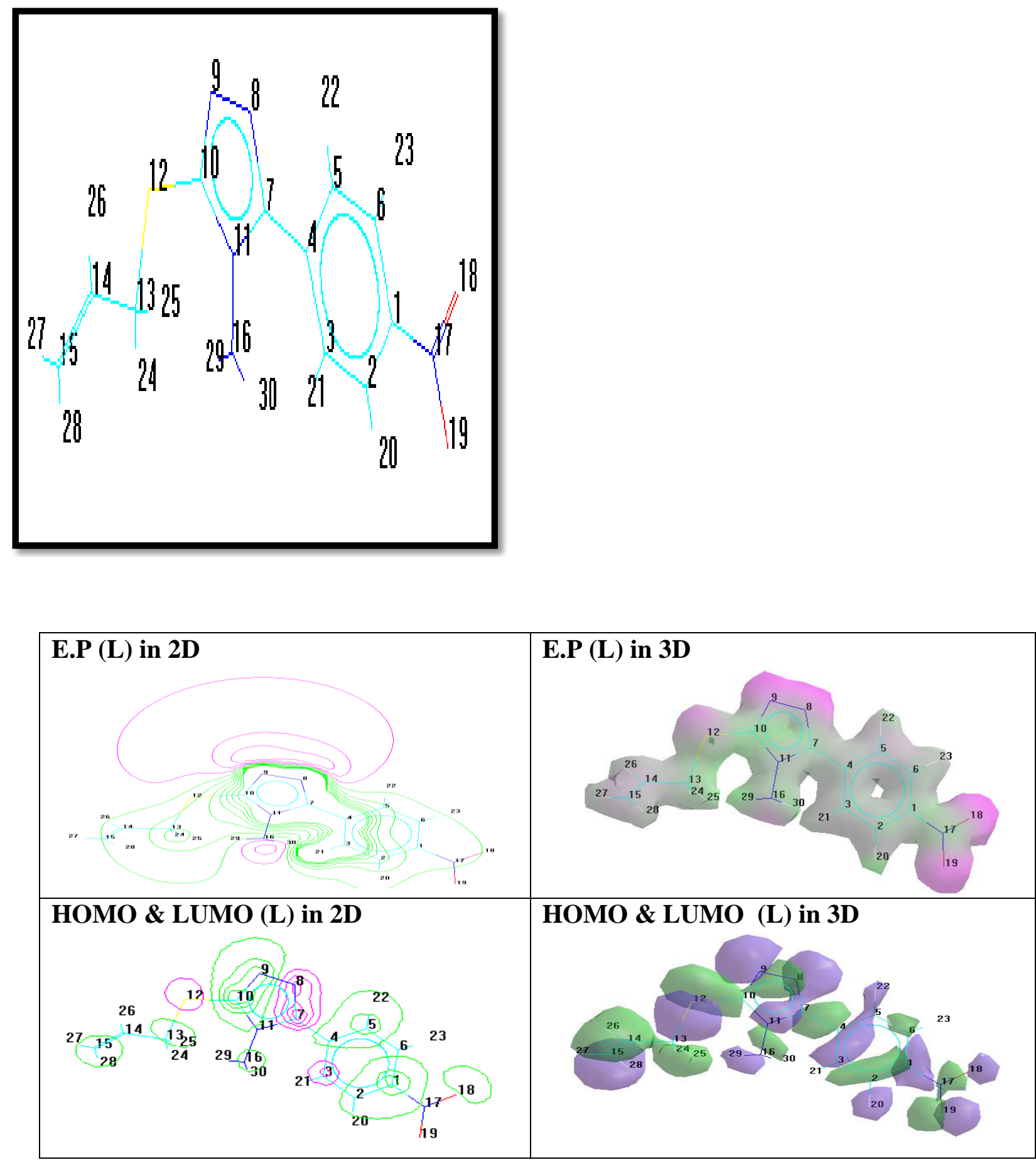

Fig.(3) HOMO, LUMO and Electrostatic potential as 2 and 3D counters for free ligand.

\section{Conclusion}

The ligand 5-(4-Nitro Phenyl)-4-Amino-3Mercapto Propenyl-1,2,4-Triazole (L) was successfully synthesized by five steps. The ligand behaves as a tridentate through pi bond, amine group and sulfur atom. The theoretical calculation data of the frequencies for the ligand agreed and help to assign unambiguously the most diagnostic bands. Theoretical electronic transitions helped to assign type of transition, and the calculation of 
energies give information about the most stable structure.

\section{References}

[1] Raafat, M. S.; "The Chemistry of Mercapto- and Thion-Substutied 1,2,4Triazole and their Utility in Heterocyclic Synthesis";ARKIVOC (ix):pp59-112; 2006.

[2] Neeraj, U.; Sanjay, K.; Murali, D. K.; Kamal, S.; and Praadep, M.; "Synthesis and Anti-Microbial Evaluation of some Novel 1,2,4-Triazole Derivatives"; Acta. Polon. Pharma. Drug. Res., 68(2):pp213-221; 2011.

[3] Quisenberry, K.; Smith, J. D.; Voehler, M.; Stec, D.; Hanusa, T. P.; and Brennessel, W.W.; "Trimethyl Silylated Allyl Complexes of Nickel. The Stabilized Bis $(\delta-$ allyl) Nickel Complex [e3-1,3$\left.\left(\mathrm{SiMe}_{3}\right)_{2} \mathrm{C}_{3} \mathrm{H}_{3}\right]_{2} \mathrm{Ni}$ and its Mono ( $\delta$-allyl) NiX (X) Br, I Derivates"; J. Am. Chem. Soc., 9(12):pp 4377- 83; 2005.

[4] Liu, J.; Guo, G.; Cong, M.; Wei, Y.C.Z.; Wei, Z.F.; Kun, L.S.; Huo, W. M.; Shengshum, H. J.; "Synthesis and Crystal Structure of $\mathrm{Ag}_{2}(\mathrm{admtrz})_{2} \quad\left(\mathrm{CF}_{3} \mathrm{CO}_{2}\right)_{2}$ (admtrz=4-amino-3, dimethyl-1,2,4triazole"; Chin. J. Stru., 21(4): pp 371-373; 2002.

[5] Shridhar, A. H.; Keshavayya. J.; and Hoskeri, "Synthesis, Characterization and Pharmacological Studies of Novel 1,3,4Oxadiazole and 1,2,4-Triazole derivatives"; Der. Chem. Sin., 2(4):pp106-114; 2011.

[6] Douglas, A. S.; Donald, M. N.; Holler, F. J.; Crouch, S. R.; Chen, S. C.; "Introduction to Analytical Chemistry"; Case bound, $1^{\text {st }}$ Ed, 2011.

[7] Silverstein, R. M.; Bassler, G.C.; and Morill, T.C.; "Spectrochemitric Identification of Organic Chemistry"; John Wiley and Sons, 1981.

[8] Alias, M. F.; Hamza, M.O.; and Kareem, T. A.; "Preparation, Structural Study,
Theoretical Treatment and Biological Activity of $\mathrm{Cr}(\mathrm{III}), \mathrm{Ni}(\mathrm{II}), \mathrm{Cd}(\mathrm{II})$ and $\mathrm{V}(\mathrm{IV})$ Complexes of Tetrdentate Ligand Bis[4Pheyl-3(2-Propenyl) Thio-1,2,4-Triazole5yl] Methane"; J. Al-Nahrain Uni. 4(2):pp18-10; 2011.

[9] Nakamoto, N.; "Infrared and Raman Spectra of Inorganic and Coordination Compounds"; John Wiley \& Sons, Inc., $6^{\text {th }}$ Ed., New Jersey; 2009.

[10] Siddiqi, K. S.; Nami, S. A.; Lutfullaha and Chebude, Y.; "Template Synthesis of Symmetrical Transition Metal Dithiocarbamates"; J. Braz. Chem. Soc., 17 (1):pp107-112; 2006.

[11] Pastorek, R.; Kameníče, J.; Husárek, J.; and Šindelář, Z.; "Binuclear dithiocarbamato complexes of nickel with 1,6-Bis (Diphenylphosphino) hexane as bridging ligand";. J. Chemica, 40: pp 53$56 ; 2001$.

[12] Figgis, B. N.; and Lewis; "The Magnetic Properties of Transition Metal Complexes"; Prog. Inorg. Chem, 6:pp 37239; 1964.

[13] Manohar, A.; Ramalingam, K.; Bocelli, G.; and Cantoni, A.; "Synthesis, Spectral and Single Crystal X-Ray Structural Studies on Bis(2,2'-bipyridine) Sulphido $\mathrm{M}(\mathrm{II})(\mathrm{M}=\mathrm{Cu}$ or $\mathrm{Zn})$ and Diaqua 2,2'bipyridine Zinc(II) Sulphate Dehydrate"; J. Ser. Chem. Soc. 75(8):pp1085-1092; 2010.

[14] Greenwood, N.N.; Ernshaw, A.; "Chemistry of Elements"; 2 ${ }^{\text {nd }} . ~ E d .$, Pergamum Press, 1981.

[15] Al-Hasani, R. A. M.; Al-Abodi, A. K.; and Kadem, S. A.; "Synthesis, Structural Study and Antibacterial Activity of Pd(II), $\mathrm{Ru}(\mathrm{III}), \quad \mathrm{Rh}(\mathrm{III}), \mathrm{Au}(\mathrm{III}) \quad$ and $\mathrm{Pt}(\mathrm{IV})$ Complexes of 4-Nitro -3-\{[4-(4Hydroxyphenyl) -2-Methyl-5-Oxo-4,5Dihydro-1H-Imidazol-1-YL] Imino $\}-1,3$ Dihydro-2Hindol-2-One"; J. Al-Nahrain. Uni. 12 (2): pp 35-45; 2009.

[16] Clark, T. A.; "Hand Book of Computational Chemistry"; John Wiley and Sons, New York, 1985. 


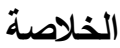

تم تحضير معقدات جديدة لـ ليكاند 0-(ع-نايترو

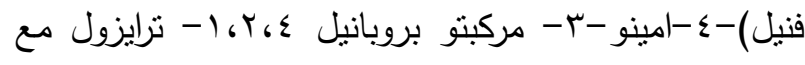

Co(II), Ni(II), Cu(II), Zn(II) \& ايونات الفلزات

Au(III)

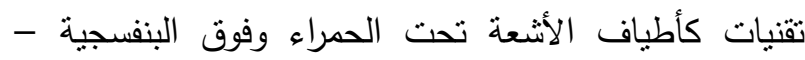

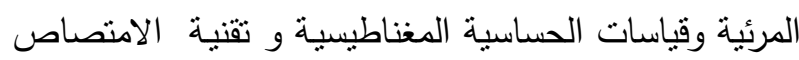

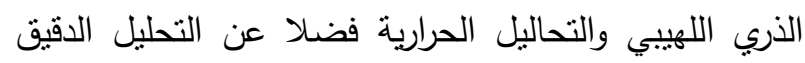

للعناصر و التوصيلية الكهربائية. من الدراسات الطيفية تم

اقتراح شكل ثماني السطوح احادي الجزيئة بالنسبة لمعقدات الذهب والنيكل والكوبلت والزنك بينما اقترح شكل ثنائي

الجزيئة بالنسبة للنحاس. تم كذللك دراسة طبيعة المعقدات

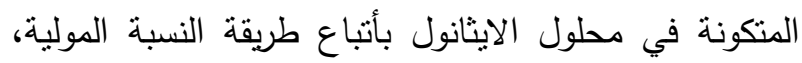

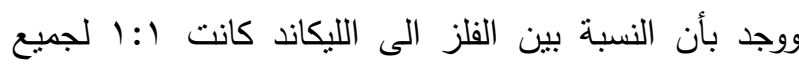

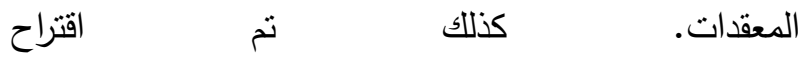

الأشكال التركيبية لهذه المركبات نظرياً في الطور

الغازي باستخدام برنامج (Hyperchem-8) بنطبيق

الميكانيك الجزيئي وشبه التجريبي في الحساب بطرق باني

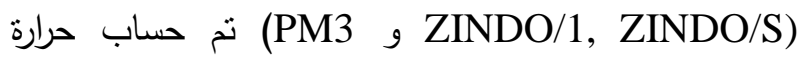

التكوين وطاقة الترابط و عزم ثنائي القطبين للمركبات المحضرة باستثناء معقد الذهب حيث استخدمت طريقة AMBER كذلك تم حساب الترددات الاهنزازية والانتقالات بنداء الالكترونية لليكاند المحضر وكذلك تم حساب الكثافة 